\author{
Piotr Puchalski \\ ORCID https://orcid.org/0000-0003-4530-959X \\ University of Wisconsin-Madison
}

\title{
POLITYKA NARODOWOŚCIOWA I KOLONIALNA ZWIĄZKU RADZIECKIEGO W UJĘCIU HISTORIOGRAFII AMERYKAŃSKIEJ
}

\author{
Nationality and Colonial Policies \\ of the Soviet Union in U.S. Historiography
}

WYRAZY KLUCZOWE: ZSRR, USA, polityka narodowościowa, kolonializm, historiografia

KEYWORDS: USSR, USA, nationality policy, colonialism, historiography

\begin{abstract}
Aвstract: Changes in American interpretations of Soviet nationality policies have reflected broader shifts in U.S. historiography of the former U.S.S.R. Notwithstanding pro-Soviet apologists, U.S. scholars initially viewed the Soviet expansion into neighboring non-Russian lands as forced and integral to the emergence of the Soviet "party-state." In effect, the Soviet rule, in particular outside of ethnic Russia, was perceived as brutal and often colonial in nature. The fall of the Soviet empire and resulting political relaxation, however, presented a turning point for the field, ushering in the so-called "archival revolution." Consequently, the topic literature increasingly interpreted Soviet policies no longer as necessarily colonial but instead responsible for generating modern nationalities, or at least national categories. At the same time, the Soviet-era ideological divisions among U.S. scholars have not completely disappeared, while the more recent postmodern tendencies have affected the field in both positive and negative ways. Theoretical approaches that encourage comparative analysis and the deconstruction of analytical categories are used productively to maintain critical distance but also carry the risk of moral relativism.
\end{abstract}

Polityka narodowościowa Związku Radzieckiego stanowiła przedmiot zainteresowania amerykańskich badaczy od zarania zimnej wojny, gdyż uważali oni wielonarodowy charakter swego geopolitycznego adwersarza za jego potencjalną słabość. Zgłębiano wtedy genezę tejże polityki w kontekście powstawania radzieckiego „państwa-partii” (party-state) i jego wczesnej ekspansji na ziemie nierosyjskie, a także starano się zrozumieć jej współczesne konsekwencje. Pierwsze amerykańskie interpretacje tematu podkreślały różne formy represji przeciwko szczepom i narodom „uwięzionym” w radzieckim imperium, szczególnie w okresie stalinowskim. Nie oddawały one jednak należycie roli, którą przywódcy owych narodowości odgrywali we współtworzonym przez nich aparacie państwowym. Po $1991 \mathrm{r}$. 
pojawiły się z kolei opracowania zarówno wysoce empiryczne, jak i porównawcze, którym zaczęło sprzyjać częściowe otwarcie poradzieckich archiwów i odprężenie w światowej polityce. W historiografii amerykańskiej nastąpił jednak również zwrot ku postmodernizmowi, który odcisnął swoje piętno na stanie dzisiejszej literatury.

R. Pipes, jeden z najważniejszych historyków ZSRR, uważał pozorne wspieranie przez bolszewików struktur narodowych swojej partii za konsekwencję marksistowskich wywodów Lenina, według których państwa narodowe miały służyć budowie socjalizmu (Pipes 1997, 21). Bolszewicy marzyli o stworzeniu nowoczesnych narodów, silników napędowych socjalizmu, aby następnie włączyć nowe twory w struktury imperium. Pipes zaznaczał jednak, że Sowieci uznali konsolidację władzy i odbudowę zniszczonej gospodarki za ważniejsze od autonomii narodowych struktur partyjnych (Pipes 1997, 244). Echa myśli Pipesa można usłyszeć w dziełach innych słynnych sowietologów, takich jak M. Malia (1994) i P. Kenez (1985), lecz zdobył on także wielu naśladowców wśród mniej znanych amerykańskich uczonych. Dla przykładu podobne założenie przyjął J. Borys, który uważał sowietyzację Ukrainy za część procesu kształtowania się Związku Radzieckiego poprzez ujednolicenie aparatu partyjnego. Obalenie ukraińskiej Rady, której członkami byli mienszewicy i eserowcy, stanowiło według Borysa część schematu powstrzymywania samostanowienia się państw socjalistycznych niepodległych od bolszewickiej Rosji (Borys 1980, 356-357). Wymienić należałoby również opracowanie W. Connora, w którym ukazuje on schemat manipulowania komunistami o poglądach „narodowych” (Connor 1974).

Pomimo tych wczesnych dzieł, jakże krytycznych wobec radzieckiej polityki narodowościowej, pisano także i w zgoła innym tonie. Dla przykładu A. J. Mayer sugerował, że Lenin nie promował samostanowienia narodów socjalistycznych jedynie w duchu marksistowskim, lecz również dla wzniecenia ruchów narodowowyzwoleńczych w zachodnich mocarstwach kolonialnych. W ten sposób Lenin miał zmusić Wilsona, Lloyda George’a i Clemenceau do przyjęcia analogicznych dyskursów o samostanowieniu narodów w wersji niekomunistycznej. Według Mayera polityka narodowościowa ZSRR nie stanowiła zatem swego rodzaju pustej skorupy czy też przekłamania, lecz zachęcały do niej bolszewików ich geopolityczne ambicje (Mayer 1964). Podobnie M. Lewin, w swojej analizie korespondencji Lenina z czasów jego rekonwalescencji (1922-1924), przedstawiał argumenty przemawiające za odróżnieniem „wielkorosyjskiego szowinizmu” Stalina od mniej złowrogiej polityki narodowościowej tego pierwszego. Dojście do władzy Stalina stanowiło dla autora koniec prawdziwej narodowej autonomii w Związku Radzieckim (Lewin 2005, 66-68). To Stalinowi przypisywał Lewin upadek autonomicznych ruchów Envera Paszy, Sułtana Galijewa i Mykoły Skrypnyka, a także zaznaczał, że status Buchary, Krymu i Ukrainy stał się obiektem ostrego konfliktu pomiędzy Stalinem a jego mistrzem, Leninem. Także i R. C. Tucker (1977) wybielał poglądy Lenina, kierując swą krytykę radzieckiej polityki narodowościowej w stronę Stalina. Przedstawiał 
on radzieckiego dyktatora jako prawicowego imperialistę i rosyjskiego mesjanistę, który na przełomie lat dwudziestych i trzydziestych przeprowadził "thermidorową" kontrrewolucję przeciw narodowym strukturom ZSRR.

Oprócz dzieł traktujących o ideologiczno-politycznym konflikcie pomiędzy różnymi ośrodkami władzy powstały również opracowania na temat konsekwencji radzieckiej polityki narodowościowej. Dotykały one następujących, powiązanych wątków: wielkiego głodu na Ukrainie w latach 1932-1933, kwestii deportacji mniejszości narodowych, a także kolonialnych taktyk rządzenia Azją Środkową. W kontekście wielkiego głodu nie sposób nie wspomnieć o słynnym dziele R. Conquesta (1987), w którym autor stwierdzał jednoznacznie, że odpowiedzialny za Hołodomor Stalin kierował się chęcią pozbycia się ludności o silnej narodowej tożsamości. W kontekście deportacji z kolei Conquest określał Sowietów mianem „Zabójców narodów” (nation killers), którzy na przemian niszczyli i rehabilitowali narody, kierując się nie marksistowskimi dogmatami, lecz prerogatywami politycznymi (Conquest 1970, 12). Było to założenie, którego dowodzili również autorzy monografii o losach konkretnych narodów czy grup etnicznych deportowanych z miejsca zamieszkania. Dla przykładu, posiłkując się źródłami przechwyconymi od Sowietów, I. M. Matley (1979) pisał, iż deportacje ingryjskich Finów zależały od stosunków politycznych ZSRR z Niemcami i Finlandią.

Przełom lat siedemdziesiątych i osiemdziesiątych stanowił w USA okres, w którym opublikowane zostały dzieła historyka rosyjskiego A. Niekricza. Oskarżał on $\mathrm{w}$ jednym $\mathrm{z}$ nich Stalina o przypisywanie całym mniejszościom narodowym zbiorowej odpowiedzialności za kolaborację z Niemcami podczas II wojny światowej, przywołując słynny mit białego konia, którego Hitler miał rzekomo dostać od wdzięcznych za uwolnienie spod radzieckiego jarzma ludów nierosyjskich (Nekrich 1981, 177-179). Poza tym amerykańskie opracowania z tamtych lat dotykały również zbrodniczych efektów kolektywizacji w Azji Środkowej. Dla przykładu, M. B. Olcott dowodziła, iż główną motywację katastrofalnej gospodarczo kolektywizacji w Kazachstanie stanowiła „destrukcja fundamentów tradycyjnej władzy” i stworzenie „nowego kazachskiego człowieka” (Olcott 1981, 125). Cenioną książką z tego okresu jest też dzieło G. J. Massella (1974), w którym autor opisywał fenomen tzw. proletariatu zastępczego, czyli azjatyckich kobiet, które zastępowały Sowietom robotniczą awangardę rewolucji potrzebną do rozbicia tradycyjnego modelu rodziny społeczeństw nomadzkich.

Nie licząc zatem opracowań komunistycznych apologetów pokroju Mayera czy Tuckera, okres zimnej wojny obfitował w publikacje ostro krytykujące zarówno założenia ideologiczne radzieckiej polityki narodowościowej, jak i jej zbrodnicze skutki podczas kolektywizacji na Ukrainie czy też deportacji mniejszości narodowych. Zapowiedź interpretacyjnych zmian, które miały niebawem nastąpić, stanowiła jednak książka o Gruzji autorstwa R. G. Suny’ego. Opisywał on w niej korienizację, czyli tworzenie przez Sowietów narodowych struktur partyjnych 
przy jednoczesnej proliferacji narodowych szkół, teatrów i czasopism (Suny 1988, 233-259). To właśnie na tym narodowotwórczym aspekcie radzieckiej polityki skupiły się amerykańskie opracowania powstałe już po okresie zimnej wojny. Impuls dla wznowienia badań w USA stanowił nie tyle sam rozpad imperium, ile jego podział dokonany wzdłuż granic narodowościowych poszczególnych republik. Suny sugerował wtedy, że marksistowska polityka narodowościowa zemściła się podczas gorbaczowskiej pierestrojki, kiedy narodowi przywódcy socjalistycznych republik stopniowo odsunęli się od Moskwy na podstawie wymyślonych pół wieku wcześniej tożsamości narodowych. Argumentował on, że Sowieci manipulowali narodowymi tożsamościami ludów nierosyjskich dzięki różnego rodzaju ankietom, spisom ludności, systemom podatkowym czy granicom administracyjnym (Suny 1993, 124-126).

Najbardziej kontrowersyjne zaprzeczenie negatywnych, zimnowojennych interpretacji radzieckiej polityki narodowościowej stanowił artykuł Y. Slezkina z 1994 r., w którym porównywał on ZSSR do mieszkania komunalnego i sugerował, iż w swoim imperium Sowieci promowali „etniczną różnorodność” (ethnic particularism). Slezkine twierdził, że zachodni uczeni źle oceniali radziecką politykę, przykładając ją do „burżujskich” standardów samostanowienia się narodów, według których narody definiowało się poprzez ich język i kulturę. Historyk ten uznawał z kolei radziecką politykę za „widowiskowo udaną próbę pomieszania przez państwo pojęć języka i kultury z biurokracją napędzaną systemem kwotowym” (Slezkine 1994b, 414). Slezkine uważał zarówno leninowską korienizację, jak i stalinowskie święta dedykowane głównym narodowościom ZSRR za próby walki z „wielkorosyjskim szowinizmem”. W monografii na temat rosyjskiego stosunku do „małych ludów północy" Slezkine komplikował jednak swoją teorię, sugerując, iż to właśnie „wielkorosyjski szowinizm”, czyli stare metody kolonialnego rządzenia tajgą i tundrą, powstrzymywały interwencjonistyczne (i zarazem ludobójcze) zapędy Sowietów (Slezkine 1994a, 390-392).

Niedługo po książce Slezkina ukazało się opracowanie L. Violi na temat reakcji rosyjskiego chłopstwa na kolektywizację. Przy jej pisaniu autorka korzystała z teorii „wewnętrznego kolonializmu” (internal colonialism) rozwiniętej dwadzieścia lat wcześniej przez A. Gouldnera (1977), który tak właśnie nazywał stalinowskie kampanie „dekułakizacyjne”. Viola opisywała zatem dekułakizację jako brutalną ekstrakcję państwowej daniny z zacofanej i obcej peryferii kolonialnej w celu sfinansowania machiny przemysłowej sowieckiej metropolii, czyli industrialnego centrum (Viola 1996, 3-12). Jednocześnie M. Gelb (1995) sugerował, iż Sowieci dekułakizowali w szczególności grupy narodowościowe o największej świadomości narodowej. Dzieła Violi i Gelba przyczyniły się do powrotu do analizowania radzieckiej polityki narodowościowej jako de facto polityki kolonialnej, a walk klasowych jako de facto zmagań na tle narodowościowym. 
Kolejny przełom $\mathrm{w}$ tym zakresie stanowił artykuł P. Holquista napisany na podstawie odtajnionych archiwaliów dotyczących „dekozakizacji”. Autor stwierdzał w nim, iż polityka eksterminacji Kozaków dońskich przez bolszewików na początku 1919 r. stanowiła radykalną manifestację polityki narodowościowej. Czystek dokonanych na Kozakach nie powodowały ani marksistowskie przesłanki, ani prawidła wojny, lecz względy rasowe. Były one bowiem aktem „profilaktycznej higieny politycznej" (prophylactic political hygiene), która stygmatyzowała w zoologiczny sposób Kozaków jako posiadającą wrodzone kontrrewolucyjne nastawienie grupę narodowościową (Holquist 1997, 139). W celu osiągnięcia czystego ciała politycznego bolszewicy uciekali się zatem do przesłanek biologicznych, mieszając ze sobą pojęcia klasy i rasy. F. Hirsch (2002) przestrzegała jednak przed zrównywaniem podobnych rasowych tendencji bolszewickich do ludobójczej polityki nazistowskiej. Zwracała ona uwagę na sowieckie zrozumienie terminu „rasa”, które miało według niej charakter raczej społeczno-historyczny aniżeli czysto rasowy. Nie oznaczało to jednak, że polityka wychodząca z założenia walki klasowej okazywała więcej szacunku dla ludzkiego życia aniżeli niemiecki hitleryzm.

Zainteresowanie amerykańskich uczonych polityką narodowościową ZSRR osiągnęło apogeum na przełomie ubiegłego i obecnego stulecia, przy czym powstałe wtedy opracowania należy sklasyfikować jako dzieła analizujące temat z perspektywy systemowej oraz na takie, które skupiły się na skutkach owej polityki w aspekcie funkcjonowania społeczności lokalnych. Artykuł T. Martina zaliczał się z pewnością do tej pierwszej kategorii. Autor poruszał w nim kwestię sowieckich czystek etnicznych z okresu stalinowskiego, twierdząc, iż deportacje mniejszości narodowych z terenów przygranicznych miały na celu konsolidację owych mniejszości, a nie stworzenie jednolitego radzieckiego państwa narodowego. Martin uważał zatem, że nie nastąpiła definitywna cezura pomiędzy stworzoną w $1913 \mathrm{r}$. przez Stalina polityką korienizacji, zakładającą dbanie o narody dawnego Imperium Rosyjskiego, a późniejszymi represjami. Przyświecał im bowiem w praktyce jeden cel (Martin 1998, 816). Według niego radzieckiej polityki narodowościowej nie powinno się rozumieć jako przejawu marksistowskiej ideologii, lecz jako rezultat zmagań sowieckiej ksenofobii z kilkoma doktrynami geopolitycznymi, m.in. $\mathrm{z}$ „doktryną Piemontu” (Piedmont Principle), według której Związek Radziecki miał stać się centrum przyciągania bezpaństwowych narodów. Innymi słowy, sowiecka paranoja związana z rzekomymi obcymi wpływami w kraju neutralizowała w interpretacji Martina możliwości pozyskania ukraińskich czy białoruskich sprzymierzeńców przy pomocy powierzchownie unarodowionych sowieckich instytucji (Martin 1998, 829-832).

W późniejszej monografii Martin określił radziecką politykę narodowościową anachronicznym terminem „akcji afirmatywnej” (affirmative action empire), który odnosi się do polityki wyrównywania szans społecznych mniejszości rasowych i narodowych w USA. Autor pisał wtedy, iż owa radziecka akcja afirmatywna 
polegała na „rozbrajaniu [rosyjskiego] nacjonalizmu poprzez tworzenie poszczególnych «form narodowych» dla nierosyjskich grup mniejszościowych" (Martin 2001, 3). Był to jednak opis tylko jednego aspektu radzieckiej polityki przestudiowanej przez Martina, a konkretnie tzw. przesłanki kolonialnej (Colonial Premise), której przeczyły inne radzieckie doktryny wymienione w jego książce (Martin 2001, 6-8). Dlatego też zarówno termin „imperium akcji afirmatywnej”, jak i główne założenie dzieła Martina spotkały się z krytyką innych amerykańskich uczonych.

W odróżnieniu od Martina, który studiował odtajnione dokumenty centralnej administracji ZSRR, aby zrozumieć wykonywanie polityki narodowościowej przez „miękkie” (soft-line) i „twarde” (hard-line) radzieckie instytucje państwowe (Martin 1999), F. Hirsch badała archiwalia pochodzące z Azji Środkowej, skupiając się na roli grup i jednostek, m.in. radzieckich etnografów, w tworzeniu się sowieckiego imperium. Hirsch dowodziła, iż rządowi rzeczoznawcy praktykujący jeszcze za czasów caratu, np. S. F. Oldenburg, zostali zatrudnieni przez Sowietów w celu zebrania danych etnograficznych na temat narodów i plemion znajdujących się na terenie ZSRR. Mieli oni następnie zinterpretować znalezione informacje w zakresie określonych celów geopolitycznych, np. do wyznaczenia odpowiednich granic pomiędzy socjalistycznymi republikami (Hirsch 2005, 21-22). Hirsch podkreślała przy tym, iż przywódcy narodowi i wodzowie plemion często manipulowali spisami ludności i gospodarczymi statystykami swoich republik, dzięki czemu uzyskiwali konkretne korzyści od rządu centralnego oraz narzędzia do walki z regionalnymi rywalami. Ostateczne decyzje dla państwa podejmowano w ramach kompromisu pomiędzy Gosplanem a Narkomatami (Hirsch 2005, 65). Hirsch zapisała się zatem w historiografii amerykańskiej jako jedna z pierwszych uczonych, którzy zwrócili uwagę na znaczenie jednostek pokroju Oldenburga w państwie uznawanym za totalitarne.

Rolą jednostek w kontekście kształtowania radzieckiej polityki narodowościowej w Azji Środkowej zainteresowali się kolejni historycy. Posiłkując się materiałami z archiwów z Moskwy i Kazachstanu, P. Michaels ukazała związki między rozwojem nowoczesnej medycyny a wykorzystywaniem jej przez Sowietów do umacniania władzy w Kazachstanie. Podkreślała ona zarówno próby kategoryzowania Kazachów jako „brudnych” i „zacofanych” przez radzieckich lekarzy i członków aparatu państwowego, jak i miejscowe reakcje wobec tej propagandy, przejawiające się poprzez nieustającą popularność medycyny domowej (Michaels 2003, 4-7). Michaels zaznaczała przy tym, iż kadry medyczne celowo tworzono w Kazachstanie głównie z kobiet, aby jednocześnie spełnić obietnicę postępu, wypromować kolaborującą środkowoazjatycką elitę kolonialną i przyczynić się do upadku tradycyjnych wartości. Chociaż państwowe kampanie na rzecz nowoczesnego macierzyństwa rozpoczęte w 1923 r. nie zdobyły dla radzieckiej władzy popularności wśród większości kazachskich kobiet, to jednak Sowietom udało się w dużej mierze wpłynąć na ich praktyki zdrowotne i uzyskać szablon dla podobnych kampanii w innych częściach imperium 
(Michaels 2003, 150-152). Wprowadzenie nowoczesnych rozwiązań podwyższyło standard życia niektórych osób, ale także umożliwiło państwu przejęcie kontroli nad społeczeństwem (Michaels 2003, 44 i n.).

Michaels i inni naukowcy stwierdzali, że radziecką politykę narodowościową w Azji Środkowej przenikało europejskie poczucie wyższości kulturowej. Dla przykładu, w swojej monografii na temat Rosyjskiego Towarzystwa Kolonialnego w Taszkencie, historyk J. Sahadeo stwierdzał, iż stosunki panujące pomiędzy oficerami carskiej armii, słowiańskimi chłopami, muzułmańskimi kobietami oraz środkowoazjatyckimi notablami odzwierciedlały zasadnicze różnice pomiędzy rosyjską misją cywilizacyjną a duchem rewolucyjnym, które ujawniły się po przejęciu przez komunistów władzy w mieście (Sahadeo 2007, 7). Według niego odzwierciedlały one zasadnicze różnice pomiędzy rosyjską misją cywilizacyjną a duchem rewolucyjnym, które ujawniły się po przejęciu w mieście władzy przez Sowietów. Wewnętrzne zaprzeczenia radzieckiej polityki narodowościowej najlepiej ilustrowała sytuacja, w której robotnicy rosyjscy odmówili swoim środkowoazjatyckim kolegom udziału w strukturach władzy pomimo nadejścia odpowiednich instrukcji z rewolucyjnej centrali w Moskwie. Taszkentem musiano zatem ze względu na ową ksenofobię rządzić $\mathrm{z}$ wojskowych baraków otaczających miasto, całkiem jak za czasów kolonialnych (Sahadeo 2007, 187-188, 207-209).

Międzywojenne próby niesienia „postępu” i „oświecenia” muzułmanom, w tym przypadku kampanie ściągania chust mieszkankom Uzbekistanu (hujum), stanowiły również temat opracowania $\mathrm{D}$. Northropa. Pisał on, że dramatyczne akty publicznego ściągania chust interpretowano raczej jako oznakę nieprzyjaznej ingerencji przypominającej czasy kolonialne aniżeli nową politykę postępu. Według Northropa istniały w tym zakresie również inne problemy dla władzy radzieckiej. Pomimo tego, iż udało się „,wyzwolić” wiele kobiet i nakłonić je do pracy w Żenotdielu czy Komsomołu, ich życie przed II wojną światową utrudniały słabość radzieckiego aparatu państwowego w Azji Środkowej oraz ciągłe „zacofanie” miejscowego ludu (Northrop 2004). Władza radziecka nie działała bowiem na terenach kolonialnych Azji Środkowej jedynie w imieniu rewolucji, lecz także w poczuciu europejskiej misji cywilizacyjnej, której symbolem stały się projekty infrastrukturalne pokroju Wielkiego Kanału Fergańskiego (Northrop 2004, 14-24). Sam tytuł monografii Northropa, czyli Veiled Empire, odnosi się zresztą zarówno do kampanii ściągania chust, jak i do ukrytej kolonialnej natury sowieckiego imperium.

Mniej krytycznie od Northropa do polityki narodowościowej odnosiła się A. Edgar, według której jej kolonialny charakter w Azji Środkowej należało oceniać nie po jej rezultatach, lecz po intencjach. Zaznaczała przy tym, że radziecki proces „wyzwalania” muzułmańskich kobiet miał w tamtym wystapił także w laickiej Turcji, a niekoniecznie w koloniach mocarstw zachodnich (Edgar 2006). Edgar uczestniczyła również we wspomnianych już amerykańskich dyskusjach na temat narodów jako konstrukcji społeczno-kulturowych i oddziaływania jednostek, 
zapoczątkowanych przez uczonych pokroju Jamesa C. Scotta (Scott 1977). Edgar np. dowodziła, że naród turkmeński powstał na podstawie konglomeratu kontrolowanych przez Sowietów miejscowych plemion nomadzkich. Turkmeńska tożsamość narodowa wyrosła poprzez skrzyżowanie radzieckiej ideologii i prerogaty w politycznych ze zwyczajami społeczno-gospodarczymi i wierzeniami religijnymi poszczególnych szczepów (Edgar 2004). Według Edgar Związek Radziecki niekoniecznie niszczył zatem narody, lecz prowadził prawdziwe procesy narodowotwórcze poprzez negocjacje z wybranymi grupami etnicznymi. Aparat sowiecki nie różnił się przy tym od innych aparatów państwowych, które podobnymi procesami nacjonalizowały swoich obywateli (Edgar 2004, 8-9).

W tym miejscu należy zaznaczyć, że jednym z najnowszych trendów historiografii amerykańskiej na temat polityki narodowościowej Związku Radzieckiego jest zainteresowanie historią sowieckich terenów przygranicznych, które z kolei wiąże się z ogólnym zainteresowaniem tak zwanymi borderlands, także wśród historyków Europy Środkowo-Wschodniej (Bartov/Weitz 2003). Według jednej $\mathrm{z}$ teorii borderlands, społeczności o mieszanej tożsamości narodowej mieszkające na takich terenach wpływają na charakter władz państw ościennych (Baud/ Schendel 2012, 3-13). M. David-Fox wysunął tego rodzaju założenie w swoich rozważaniach na temat natury rosyjskiej nowoczesności, w której argumentował, iż zjawiska industrializacji i biurokratyzacji stanowiły rezultat zwiększonego przepływu osób i informacji na borderlands Związku Radzieckiego (David-Fox 2015, 1-18). Bardziej konkretnie koncept borderlands ujęła K. Brown w swojej historii XX-wiecznego Polesia, którą ukazała z perspektyw polskiej, radzieckiej i lokalnej. Według Brown zarówno administracja polska, jak i radziecka starały się w okresie międzywojennym uczynić region narodowo homogenicznym. W przypadku Polesia po stronie radzieckiej pierwotnie nie udawało się to nie tylko ze względu na opór rdzennych mieszkańców, którzy nie czuli specjalnej więzi z resztą państwa, lecz także ze względu na źle zorganizowaną biurokrację i zbyt restrykcyjne kategorie narodowe zdefiniowane przez Sowietów. Mieszkańcy Polesia przybrali narzucone im przez państwo narodowości dopiero podczas czystek i deportacji w okresie stalinowskiego terroru. Utożsamianie się z narodowością oficjalnie uznawaną za jedną z sowieckich mogło stanowić bowiem korzyść dla osób na zesłaniu, jednocześnie z narodowości raz przybranej nie dało się łatwo zrezygnować. Brown pisała zatem, iż Związek Radziecki nie stanowił wcale „więzienia narodów”, lecz sowieckie „tożsamości narodowe same w sobie stanowiły kolonie karne dla jednostek zawieszonych pomiędzy nimi” (Brown 2009, 11).

Podobny wniosek wynika z lektury opracowania S. Redlicha (2012) na temat Żydowskiego Komitetu Antyfaszystowskiego, w którym opisane zostały zmienne postawy radzieckiego aparatu represji wobec Żydów w czasie wojny i po niej. Zaznacza on oczywiście, że pozycja Żydów zależała od polityki, ale kategorii Żyda samej w sobie nie poddawano dyskusji. Redlich podaje w tym kontekście przykład 
Henryka Erlicha i Wiktora Altera, członków polskiego Bundu, którzy po wielu nieudanych próbach przekonania Sowietów do swojej polskiej narodowości zostali zamordowani jako żydowscy działacze. Równie ciężkie prześladowania dotknęły polskie kobiety deportowane w głąb Związku Radzieckiego ze wschodnich kresów napadniętej Polski. Jak pisze K. B. Jolluck, Polki represjonowano wyjątkowo ciężko w gułagach i innych miejscach zesłania ze względu na ich narodowość i płeć. Jolluck wskazuje jednak, że bohaterki jej monografii nie traktowały żadnego z tych wyznaczników tożsamości jako „kolonii karnej”, lecz identyfikowały się ze swoimi rodaczkami w ramach pewnego rodzaju sprzeciwu wobec polityki zwalczania narodów nieradzieckich i niszczenia różnic pomiędzy płciami (Jolluck 2002).

$\mathrm{Na}$ koniec warto wymienić popularne ostatnimi czasy w USA podejście do pisania historii z perspektywy transnarodowej lub ponadnarodowej, czyli transnational approach. Do prób przyjęcia takiego podejścia w historiografii Związku Radzieckiego zaliczyć należy m.in. książkę P. Babirackiego, która stanowi ciekawą dywagację o charakterze radzieckiej „miękkiej siły” (soft power) w Polsce okresu stalinizmu. Autor ukazał w niej ponadnarodowe środowiska zawodowe i polityczne działające na terenie powojennego imperium sowieckiego, np. stowarzyszenia naukowców i reżyserów teatralnych, które starały się w sposób łagodny promować socjalistyczną władzę pomimo kontrskutecznych w tym zakresie działań stalinowskiego aparatu represji (Babiracki 2015, 235-237). Jako przykład opracowań dotyczących kwestii narodowościowej, które stosują transnational approach, wymienić można $\mathrm{z}$ kolei artykuł na temat schematów migracji narodowościowych na terenie Związku Radzieckiego. Jego autorzy zastanawiają się w nim: „czy i dlaczego migranci [...], poprzez zamieszkanie w innym państwie związkowym, stali się bardziej narodowi, narodowo obojętni czy jeszcze inni” (Siegelbaum/Page Moch 2016, 986).

W ramach podsumowania należy zauważyć, iż historiografia amerykańska powstała po $1991 \mathrm{r}$. umniejszała zdolność radzieckiej administracji centralnej do kontrolowania narodów nierosyjskich i relacji pomiędzy nimi, szczególnie w okresie międzywojennym. Zamiast tego podkreślano potrzebę negocjowania z poszczególnymi grupami w celu zapewnienia sobie ich poparcia dla projektu socjalistycznego. Historycy pokroju Hirsch i Edgar zaznaczali rolę etnografów i plemiennych wodzów w kształtowaniu radzieckiej polityki narodowościowej w Azji Środkowej. Ich badania umożliwiła oczywiście „rewolucja archiwalna”, która nastąpiła ćwierć wieku temu, a dzięki której Amerykanie uzyskali dostęp do rosyjskich archiwów i nie musieli już posiłkować się wyłącznie samizdatem, radziecką prasą, przemyconymi dokumentami i sprawozdaniami uchodźców politycznych. Powoli odchodzi się od systemowego podejścia do tematu, jakie stosował Martin w przypadku swojego „imperium akcji afirmatywnej”, a zamiast tego rośnie zainteresowanie borderlands i transnational approach. Pomimo tych zainteresowań, wspólnych dla badaczy zarówno Związku Radzieckiego, jak i Europy Środkowo-Wschodniej, nadal brakuje należytego kontaktu i wymiany spostrzeżeń pomiędzy 
obiema grupami. Jak zostało to opisane w niniejszym przeglądzie, wielu uczonych interpretowało rozpad imperium ZSRR wzdłuż dzisiejszych granic jako konsekwencję moskiewskiej polityki tworzenia kategorii narodowych. Naukowcy zajmujący się historią naszego regionu mają jednak zgoła inne zdanie na ten temat, podkreślając znaczenie polskiej kultury dla powstania niepodległej Ukrainy, Białorusi i Litwy (Snyder 2003; Weeks 2015).

Najnowsze opracowania na temat kwestii narodowościowej Związku Radzieckiego nie skupiają się już na określonym miejscu i narodzie, lecz podążają za postmodernistyczną tendencją amerykańskiej akademii do dekonstruowania kategorii analitycznych. Do jej pionierów należą naukowcy kojarzeni z nowoczesną szkołą nacjonalizmu (Anderson 2006; Brubaker 2004; Gellner 2008; Hobsbawm 2012). To właśnie w szczególności kwestionowanie kategorii narodu w amerykańskim środowisku humanistycznym urosło ostatnimi czasy do rozmiarów imperatywu: w mniej lub bardziej bezpośredni sposób wymaga się go od młodych naukowców. Przy czym funkcjonuje również termin performative turn, odnoszący się do analizowania owych kategorii pod kątem ich „odgrywania” przez postaci historyczne, np. respondentów ankiet naukowych. Popularność takiego podejścia w naukach humanistycznych dobrze ilustruje fakt, iż owo odgrywanie (performance) kategorii, w tym tożsamości seksualnych czy też płciowych (gender), stanowiło w 2018 r. temat przewodni konwencji Association for Slavic, East European, \& Eurasian Studies (ASEEES 2018), a także jednego z najnowszych numerów czasopisma The Slavic Review (Mole 2018).

Zastosowanie postmodernistycznych warsztatów teoretycznych - dekonstrukcja kategorii, podejście transnarodowe - pozwalają historykowi na utrzymanie krytycznego dystansu do materiału źródłowego. Przy czym warsztaty owe zachęciły historyków pokroju Hirsch do konstruktywnego przestudiowania oddziaływania jednostek na panujące ustroje społeczno-polityczne. W praktyce istnieje jednak ryzyko, że postmodernizm stopniowo staje się zakamuflowaną wersją marksizmu kulturowego, według którego historia jest nieprzerwanym pasmem zmagań cywilizacji, a konkretnie Zachodu (burżuazji) z kulturami pozaeuropejskimi (proletariatem) (Peterson 2018, 306-307). Jest to zarazem ryzyko odejścia od pisania empirycznego i oceny konkretnych fragmentów historii na rzecz nadmiernej relatywizacji zjawisk. Już umniejsza się - chociaż nie zawsze z premedytacją - znaczenie ideologii marksistowskiej dla ludobójstw dokonanych na narodach, a skupia się na jej rzekomo złym wykonaniu, podobnych zjawiskach rzekomo występujących na Zachodzie, a nawet dobrych intencjach radzieckiej polityki. Zapomina się, że każda ideologia kolektywu wyzuta $\mathrm{z}$ wartości takich jak jednostkowa wolność słowa czy sumienia, a jednocześnie oparta na tożsamości grupowej - klasowej bądź rasowej - nieuchronnie prowadzi do ludobójstwa. 


\section{Bibliografia}

ANDERson, B. (2006), Imagined Communities: Reflections on the Origin and Spread of Nationalism. New York.

Babiracki, P. (2015), Soviet Soft Power in Poland: Culture and the Making of Stalin's New Empire, 1943-1957. Chapel Hill/North Carolina.

Bartov, O./Weitz, E. D. (red.) (2013), Shatterzone of Empires: Coexistence and Violence in the German, Habsburg, Russian, and Ottoman Borderlands. Bloomington/Indiana.

BAud, M./Schendel, W. (2012), A Comparative Approach to Borderlands. W: Hämäläinen, P./ Johnson, B. H. (eds.), Major Problems in the History of North American Borderlands: Documents and Essays. Boston/Massachusetts, 3-13.

Borys, J. (1980), The Sovietization of Ukraine, 1917-1923: The Communist Doctrine and Practice of National Self-Determination. Edmonton/Alberta.

Brown, K. (2009), A Biography of No Place. Cambridge/Massachusetts.

BrubaKer, R. (2004), Ethnicity Without Groups. Cambridge/Massachusetts.

Connor, W. (1984), The National Question in Marxist-Leninist Theory and Strategy. Princeton/ New Jersey.

ConQuest, R. (1970), The Nation Killers: The Soviet Deportation of Nationalities. Londyn.

Conquest, R. (1987), The Harvest of Sorrow: Soviet Collectivization and the Terror-Famine. New York.

DaviD-Fox, M. (2015), Crossing Borders: Modernity, Ideology, and Culture in Russia and the Soviet Union. Pittsburgh/Pensylwania.

Edgar, A. L. (2004), Tribal Nation: The Making of Soviet Turkmenistan. Princeton/New Jersey.

EdGar, A. L. (2006), Bolshevism, Patriarchy, and the Nation: The Soviet 'Emancipation' of Muslim Women in Pan-Islamic Perspective. W: Slavic Review. LV/2, 252-272.

Gelb, M. (1995), An Early Soviet Ethnic Deportation: The Far-Eastern Koreans. W: The Russian Review LIV/3, 389-412.

Gellner, E. (2008), Nations and Nationalism. Ithaca/New York.

Gouldner, A. (1977), Stalinism: A Study in Internal Colonialism. W: Telos. XXXIV, 5-48.

HirSCH, F. (2000), Toward an Empire of Nations: Border-Making and the Formation of Soviet National Identities. W: The Russian Review. LIX/2, 201-226.

HiRSCH, F. (2002), Race without the Practice of Racial Politics. W: Slavic Review. LXI/1, 30-43.

Hirsch, F. (2005), Empire of Nations: Ethnographic Knowledge \& the Making of the Soviet Union. Ithaca/New York.

Hobsbawm, E. J. (2012), Nations and Nationalism since 1780: Programme, Myth, Reality. Cambridge/ Massachusetts.

Holquist, P. (1997), „Conduct Merciless Mass Terror”: Decossackization on the Don, 1919. W: Cahiers du monde russe. XXXVIII/1, 127-162.

Jolluck, K. R. (2002), Exile and Identity: Polish Women in the Soviet Union During World War II. Pittsburgh/Pensylwania.

Kenez, P. (1985), The Birth of the Propaganda State: Soviet Methods of Mass Mobilization, 1917-1929. Cambridge/Massachusetts.

Lewin, M. (2005), Lenin's Last Struggle. Ann Arbor/Michigan.

Malia, M. (1994), The Soviet Tragedy: A History of Socialism in Russia, 1917-1991. New York.

Martin, T. D. (1988), The Origins of Soviet Ethnic Cleansing. W: The Journal of Modern History. LXX/4, 813-861.

Martin, T. D. (1999), Interpreting the new archival signals: Nationalities policy and the nature of the Soviet bureaucracy. W: Cahiers du monde russe. XL/1, 113-124.

Martin, T. D. (2001), The Affirmative Action Empire: Nations and Nationalism in the Soviet Union, 1923-1939. Ithaca/New York. 
Massell, G. J. (1974), The Surrogate Proletariat: Moslem Women and Revolutionary Strategies in Soviet Central Asia, 1919-1929. Princeton/New Jersey.

Matley, I. M. (1979), The Dispersal of the Ingrian Finns. W: Slavic Review. XXXVIII/1, 1-16.

MaYer, A. J. (1964), Wilson vs. Lenin: Political Origins of the New Diplomacy 1917-1918. Cleveland/ Ohio.

Michaels, P.A. (2003), Curative Powers: Medicine and Empire in Stalin's Central Asia. Pittsburgh/ Pensylwania.

Mole, R. C. M. (2018), Introduction to „Soviet and Post-Soviet Sexualities”. W: Slavic Review. LXXVII/1, 1-5.

Nekrich, A. (1981), The Punished Peoples: The Deportation and Fate of Soviet Minorities at the End of the Second World War. New York.

Northrop, D. (2004), Veiled Empire: Gender and Power in Stalinist Central Asia. Ithaca/New York. Olcotт, M. B. (1981), The Collectivization Drive in Kazakhstan. W: The Russian Review. XL/2.

Peterson, J. B. (2018), 12 Rules for Life. An Antidote to Chaos.

PIPES, R. (1997), The Formation of the Soviet Union: Communism and Nationalism, 1917-1923. Cambridge/Massachusetts.

RedLICH, S. (2013), War, the Holocaust and Stalinism. New York.

SAHAdeO, J. (2007), Russian Colonial Society in Tashkent, 1865-1923. Bloomington/Indiana.

Scotт, J. C. (1977), The Moral Economy of the Peasant: Rebellion and Subsistence in Southeast Asia. New Haven/Connecticut.

Siegelbaum, L. H./Page Moch, L. (2016), Transnationalism in One Country? Seeing and Not Seeing Cross-Border Migration within the Soviet Union. W: Slavic Review. LXXV/4, 970-986.

Slezkine, Y. (1994a), Arctic Mirrors: Russia and the Small Peoples of the North. Ithaca/New York.

SLezkine, Y. (1994b), The USSR as a Communal Apartment, or How a Socialist State Promoted Ethnic Particularism. W: Slavic Review. LIII/2, 414-452.

SNyder, T. (2003), The Reconstruction of Nations: Poland, Ukraine, Lithuania, Belarus, 1569-1999. New Haven/Connecticut.

SNYDER, T. (2012), Bloodlands: Europe between Hitler and Stalin. New York.

SunY, R. G. (1988), The Making of the Georgian Nation. Bloomington/Indiana.

SunY, R. G. (1993), The Revenge of the Past: Nationalism, Revolution, and the Collapse of the Soviet Union. Palo Alto/Kalifornia.

ASEEES Convention Theme (2018). W: http://www.aseees.org/convention/2018-convention-theme [dostęp 11.05.2018].

Tucker, R.C. (1977), Stalinism as Revolution from Above. W: Tucker, R. C./Brus, W. (red.), Stalinism: Essays in Historical Interpretation. New York, 77-110.

Viola, L. (1996), Peasant Rebels under Stalin: Collectivization and the Culture of Peasant Resistance. New York.

Weeks, T. R. (2015), Vilnius Between Nations, 1795-2000. DeKalb/Illinois. 